\title{
Gorba kävi täällä
}

\section{Gorba tulee - oletko valmis? Pienoisnäyttely Pohjois-Pohjanmaan museossa Oulussa 10.9. -10.11 .2019 .}

Pohjois-Pohjanmaan museon pienoisnäyttely Gorba tulee - oletko valmis? kuvaa Mihail Gorbatšovin ja hänen puolisonsa Raisa Gorbatšovan vierailua Oulussa lokakuussa 1989 ja se oli esillä ajankohtana, jolloin vierailusta oli kulunut täsmälleen kolmekymmentä vuotta. Työryhmän Pia Koivunen (Turun yliopisto), Tiina Kinnunen (Oulun yliopisto), Juri Kovaljeff (Museo- ja tiedekeskus Luuppi) ja Jonna-Maria Mölläri (Pohjois-Pohjanmaan museo) laatima näyttely on aiheeltaan suorastaan riemastuttava ja kytkee oivaltavasti yhteen politiikan suuret linjat, kylmän sodan päättymisen ja muuttuvan maailman sekä hyvin pienen, paikallisen ja henkilökohtaisen. Näyttelyssä tämä kytkös tiivistyy kysymykseen "Missä sinä olit, kun
Gorba piipahti Oulussa?” Näyttelykokonaisuus kytkeytyy FT, tutkijatohtori Pia Koivusen tutkimustyöhön Gorbatšovin vierailusta sekä laajemmin valtiovierailuista ja niiden muistamisesta. Myös Koivunen itse löysi tutkimuksensa aikana linkin oman lapsuutensa ja maailmanhistorian välillä, kun hän sai tietää näkyvänsä ystävineen neuvostoliittolaisella uutisfilmillä vilkuttamassa Gorbatšoville.

Pienoisnäyttely mahdollistaa oman elämän tapahtumien ajoittamisen suhteessa historiallisiin muutoksiin ja muistuttaa Gorbatšovin vierailuun kiinnittyneestä optimismista, kylmän sodan päättymisestä ja Suomen kansainvälisen aseman muutoksista. Kulunut kolmenkymmenen vuoden aika tarjoaa sopivan muisteluetäisyyden ja antaa mahdollisuuksia nostalgisiin tunteisiin sekä niille, jotka ovat olleet vierailun aikana lapsia, että myös vanhemmille, jotka muistelevat esimerkiksi omaa opiskeluaikaansa. Samalla vierailu

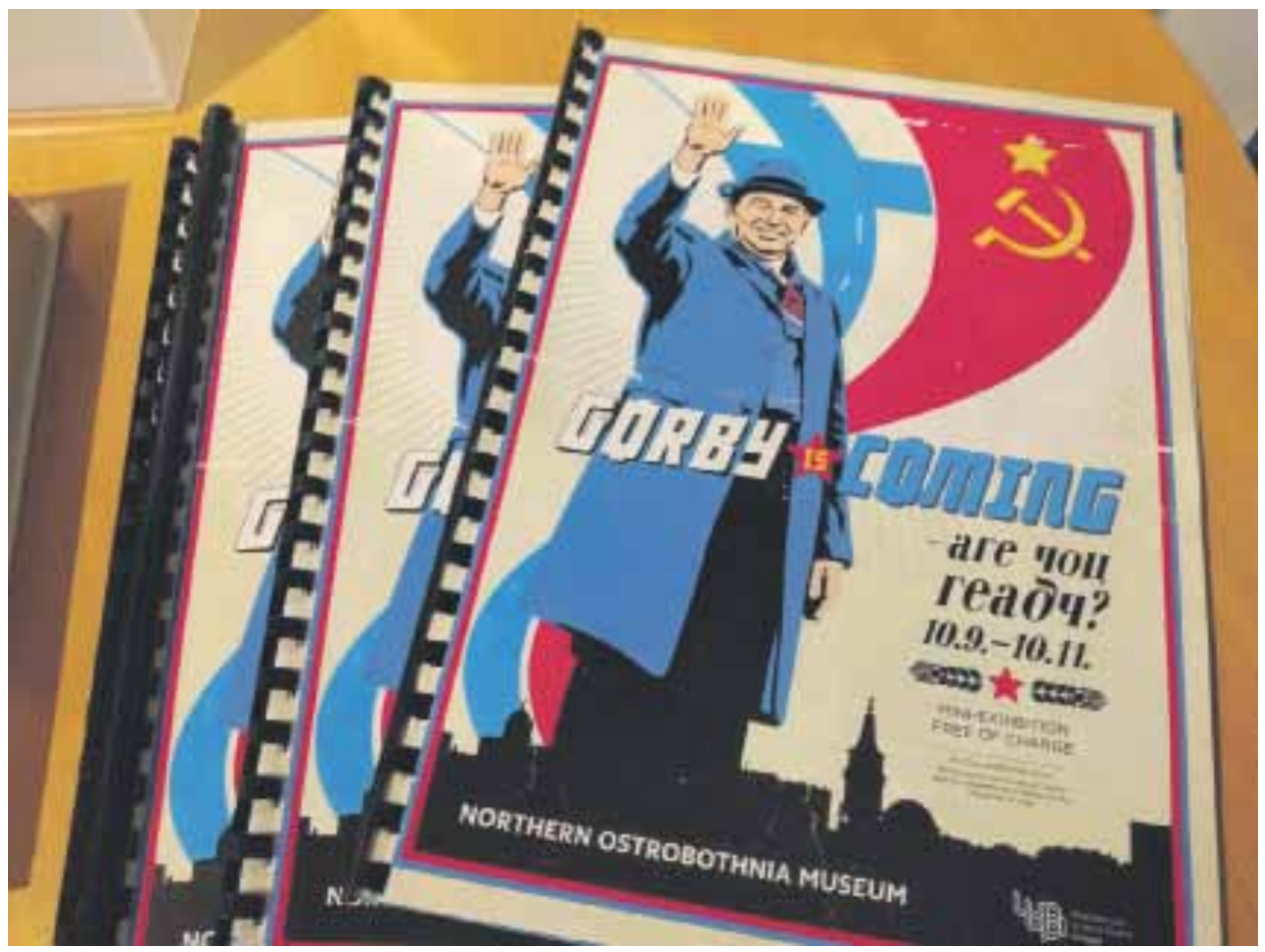

Näyttelyn tekstit esittelevät niin neuvostojohtajan vierailua Ouluun kuin kylmän sodan päättymisen poliittista tilannetta. Kuva: Riikka Taavetti. 


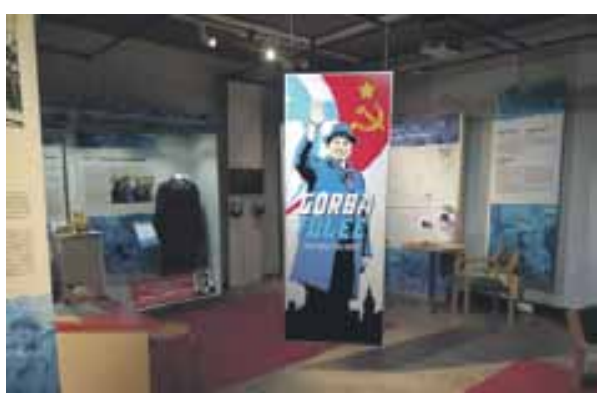

Gorba kävi täällä -pienoisnäyttelyssä PohjoisPohjanmaan museossa Oulussa maailmanpolitiikka yhdistyy paikallisiin ja henkilökohtaisiin muistoihin. Kuva: Riikka Taavetti.

muistuttaa ajasta, joka on lähellä, muisteltavan etäisyyden päässä, mutta kuitenkin varsin toinen: Oulun hetkellinen Gorba-huuma tuntuu nykypäivästä katsottuna ällistyttävältä ja monet vierailuun liittyvät piirteet, kuten kertomukset kouluissa askarrelluista Suomen ja Neuvostoliiton lipuista lämpimän huvittavilta.

Rakenteeltaan näyttely koostuu seliteteksteillä varustettujen esinevitriinien lisäksi lehtileikkeistä, joita voi selata näytöltä sekä katseltavana ja kuunneltavana olevista haastatteluista, uutispätkistä ja minidokumentista. Näyttelyyn laaditut tekstit ovat tyyliltään erittäin miellyttäviä ja niistä välittyy historiallisesti tasapainoinen kuva vierailuun kytkeytyneistä teemoista. Tekstejä ei myöskään ole liikaa yhdellä vierailulla luettavaksi, mikä kertoo onnistuneesta valinnasta - kerrottavaa niin itse vierailusta kuin siihen liittyvistä poliittisista kysymyksistä olisi varmasti ollut enemmänkin. Gorbatšovin vierailuun liittyvää esineistöä on oikeastaan hämmästyttävän paljon ja se on kerätty kekseliäästi. Kiinnostavia ovat esimerkiksi neuvostojohtajan tervetulotoivotuksin varustetut kyltit, jotka tehtiin vierailua varten, mutta joita ei lopulta oululaisliikkeiden ikkunoissa nähty. Ehdottomasti hämmentävin yksityiskohta näyttelyssä on suunnattoman kokoinen Urho Kaleva Kekkosen nenä. Siihen liittyvässä vierailun valmisteluja kuvaavassa tekstissä kerrotaan, miten Oulun kaupunki siivosi ennen neuvostojohtajan saapumista keskustasta pois Rotuaaria koristaneen veistosnäyttelyn. Oululaiset viranhaltijat arvioivat - todennäköisesti aivan oikein - että kansantaiteilija Matias Keskisen työ, kolmimetrinen Kekkosen kasvokuva, olisi herättänyt kummastusta kansainvälisessä lehdistössä. Siirto-operaation aikana patsas rikkoontui, mistä syystä siihen kuulunut nenä, samoin kuin tapausta kuvaava lyhyt dokumenttielokuva, voi nyt muistuttaa vierailusta näyttelyssä.

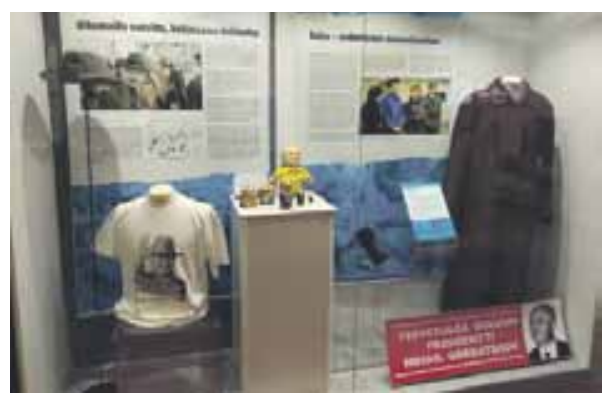

Gorbatšovin vierailua varten valmistettiin tervetulokylttejä, joita ei kuitenkaan nähty oululaisliikkeiden ikkunoissa. Kuva: Riikka Taavetti.

Jo koottujen muistitietohaastattelujen ja -kirjoitusten lisäksi näyttely kannustaa vieraita jättämään omat muistonsa seinälle. Vaikka näyttelyä tällä tavalla hyödynnetäänkin edelleen muistitiedon keruuseen, jo koottua muistitietoa olisi voinut ujuttaa enemmänkin mukaan nyt esillä olevaan näyttelyyn. Muistitietokatkelmat tarjoavat mielenkiintoisia ja koskettavia näkökulmia siihen, mitä Gorbatšovin vierailu - tai toisaalta esimerkiksi pettymys siitä, ettei odotettua vilkutusta onnistunutkaan näkemään - olivat merkinneet katsojille. Ehkä muistitietokatkelmia olisi voinut olla mukana myös kuunneltavana, sillä nyt kuultavina olevilla videohaastatteluilla pääsevät ääneen vierailun järjestelyihin osallistuneet sekä muuten tunnetut henkilöt, eivät tavalliset katujen varsille kerääntyneet oululaiset. Samoin kartta tai kuvat, joihin muistitietokatkelmat olisi liitetty, olisi tehnyt näyttelystä nykyistäkin monipuolisemman.

Yleisölle tarjottu mahdollisuus osallistua näyttelyn kokoamiseen kirjoittamalla omia muistojaan purkaa rajaa museovieraan, osallistujan ja tutkimuskohteen välillä. Samalla se asettaa edelleen jossain määrin poikkeuksellisella tavalla kyseenalaiseksi museon yksinoikeuden päättää esitettävästä tarinasta. Ainakin jokaisella kävijällä on mahdollisuus tuottaa oma osansa kertomukseen sekä halutessaan vahvistaa tai haastaa näyttelyn laatijoiden tulkintoja. Lisäksi itsessään melko pieni näyttely laajenee muistitiedon avulla omien seiniensä ulkopuolelle: näyttelyyn on liitetty erilaisia tapahtumia, ja muistoja Gorban vierailusta kerätään edelleen sähköpostitse sekä tätä tarkoitusta varten luodussa Facebook-ryhmässä.

Koska muistitieto on näyttelyssä keskeisessä osassa, näyttely kommentoi onnistuneesti myös muistamisen rajoitteita ja muistin haurautta. Erityisen kiinnostavaa yksityiskohta on muis- 
toissa usein esiintyvä Gorbatšovin ensimmäinen matkapuhelu, jonka monet sijoittavat Ouluun ja Teknologiakylään, vaikka puhelu soitettiin Helsingistä. Näyttelyssä matkapuhelin on sijoitettu Mihail Gorbatšovia ja Raisa Gorbatšovaa sekä heidän kansainvälistä mainettaan esittelevään vitriiniin ja Oulun-vierailuun keskittyvässä vitriinissä vielä palataan muistitiedossa toistuvaan puhelun sijoittamiseen Ouluun. Muistitietoon liittyy myös näyttelykäynnillä kuulemani keskustelu, jossa museovieraat pohtivat, oliko erään vierailua muistelleen mainitsema kevyen liikenteen silta tosiaan paikallaan jo vuonna 1989. Vaikka siltaa ei olisi ollutkaan ja vaikka Gorba ei soittanut kuuluisaa puhelua juuri Oulusta, molemmat näistä ovat esimerkkejä siitä, miten muisti tuottaa yhteyksiä ajallisesti yhteensopimattomien tapahtumien välille. Oulun ja nykyaikaisen teknologian kytkös kannustaa sijoittamaan myös matkapuhelun juuri vierailusta hullaantuneeseen kaupunkiin.

Näyttelystä jää vierailijalle päällimmäiseksi tunnelmaksi Gorbatšovin hahmoon tiivistyvä 1980-luvun lopun optimismi. Lisäksi hämmästyttävältä tuntuu, miten monella vaikuttaa olevan muistoja vierailusta ja Gorbatšovista, kun niitä vain ymmärretään kysyä. Omiin 1980-luvulle sijoittuviin lapsuusmuistoihini valtiovierailu ei kiinnity, varmaankin juuri siksi, kuten Leninmuseon eläkkeellä oleva johtaja Aimo Minkkinen näyttelyssä kuullussa haastattelussa totesi, että Tampere jäi yllättäen paitsi Gorbatšovin vierailusta. Valtiovierailun sijaan muistankin Tampereen keskustasta sabluunalla tehdyn seinäkirjoituksen, jossa luki "Gorba on kova jätkä". Tämän muistikuvan materiaalisia jälkiä ei taida enää löytyä mistään.

Näyttelyyn voi tutustua myös nettisivulla https://www.ouka.fi/oulu/luuppi/gorba-tulee. Gorbatšovin vierailun muistoja kertään sähköpostitse: gorbaoulussa@gmail.com sekä Facebook-ryhmässä: https://www.facebook. com/groups/413370846137683/.

Riikka Taavetti

\section{Toveri lapsi odottaa äitiä}

Toveri lapsi (Seltsimees laps, Viro 2018). Käsikirjoitus ja ohjaus Moonika Siimets. Pääosissa Helena Maria Reisner, Tambet Tuisk, Eva Koldits, Liina Vahtrik, Juhan Ulfsak, Julia Aug, Lembit Peterson, Maria Klenskaja.

Moonika Siimetsin (s. 1980) käsikirjoittama ja ohjaama elokuva Toveri lapsi perustuu lastenkirjailija Leelo Tungalin (s. 1947) omiin lapsuusmuistoihin, jotka ovat ilmestyneet kolmena kirjana ja elokuvan myötä myös yhteispainoksena. Ensimmäinen osa on julkaistu suomeksi tänä vuonna Anja Salokanteleen ja Heli Laaksosen käännöksenä nimellä Toveri lapsi: vielä yksi kertomus onnellisesta lapsuudesta (Arktinen Banaani). Viron itsenäisyyspäiväksi 2018 valmistunut elokuva keräsi kotimaassa täysiä saleja ja on ollut teatterilevityksessä myös Suomessa. Elokuvassa eletään Neuvosto-Virossa, aivan 1950-luvun alussa. Asiat näytetään, paljoakaan ei selitetä, mihin lapsen näkökulma on omiaan. On kuitenkin hyvä tietää, että kirjailijan äiti oli Tallinnan eteläpuolella sijaitsevan Ruilan moisiossa toimineen koulun rehtori, joka joutui Siperiaan opetettuaan lapsille vääränlaista historiaa. Toisin kuin elokuvassa, Tungal oli vasta 3-vuotias, kun äiti vietiin pois, ja hän eli sen jälkeen opettajaisänsä kanssa odottaen äidin paluuta.

Elokuvan alussa äiti Helmes (Eva Koldits) kertoo kuusivuotiaalle Leelolle (Helena Maria Reisner), että joskus, kun on oikein paha olla, voi auttaa, että puhuu puille. Leelo haluaa tietää, kuuntelevatko puut. Samana päivänä perhe muuttaa pois isosta talosta. Nalle jää ikkunalaudalle nököttämään. Uusi koti on vaatimaton mökki kävelymatkan päässä. Isä Feliks (Tambet Tuisk) nakuttelee rikkinäisten ikkunalasien paikalle vanerilevyjä. Leelo livahtaa ulos ja kävelee sateessa takaisin kartanoon. Nyt siellä on vieras täti (Julia Aug). Leelo nappaa nallensa ja piiloutuu, mutta täti löytää hänet. Äiti juoksee tiellä vastaan, ja täti nuhtelee äidin venäjäksi: Leelo on huonosti kasvatettu lapsi. Pian sotilaat tulevat tutkimaan perheen asunnon, ja äiti viedään kuorma-autolla pois. Leelo uskoo, että se on hänen syytään. Koska äiti on sanonut jäähyväisiksi, että nyt Leelon pitää olla kiltti tyttö, hän yrittää parhaansa mukaan; sittenhän äiti voi tulla takaisin. Välillä kun tuntuu oikein vaikealta, Leelo puhuu puille ja toivoo, että ne kuulevat. Ja ehkä auttavat.

Siimets kertoo tarinan Leelon näkökulmasta, 